\title{
Identification of the Hair Cell Soma-1 Antigen, HCS-1, as Otoferlin
}

\author{
Richard J. Goodyear $^{1}$, P. Kevin Legan ${ }^{1}$, Jeffrey R. Christiansen ${ }^{2}$, Bei Xia ${ }^{3}$, Julia Korchagina ${ }^{1}$, \\ Jonathan E. Gale ${ }^{4}$, Mark E. Warchol ${ }^{5}$, Jeffrey T. Cormin ${ }^{3}$, and Guy P. Richardson ${ }^{1}$, \\ ${ }^{1}$ School of Life Sciences, University of Sussex, Falmer, Brighton, BN1 9QG, UK \\ ${ }^{2}$ Sensory Neuroscience Research Center and Neuroscience Graduate Program, West Virginia University School of Medicine, One \\ Medical Center Drive, Morgantown, WV 26506-9303, USA \\ ${ }^{3}$ Department of Neuroscience, University of Virginia School of Medicine, 409 Lane Road, Charlottesville, VA 22908-1392, USA \\ ${ }^{4}$ UCL Ear Institute, University College London, 332 Gray's Inn Road, London, WC1X 8EE, UK \\ ${ }^{5}$ Department of Otolaryngology, Washington University School of Medicine, 660 South Euclid Avenue, St. Louis, MO 63110, \\ USA
}

Received: 12 July 2009; Accepted: 5 August 2010; Online publication: 31 August 2010

\begin{abstract}
Hair cells, the mechanosensitive receptor cells of the inner ear, are critical for our senses of hearing and balance. The small number of these receptor cells in the inner ear has impeded the identification and characterization of proteins important for hair cell function. The binding specificity of monoclonal antibodies provides a means for identifying hair cellspecific proteins and isolating them for further study. We have generated a monoclonal antibody, termed hair cell soma-1 (HCS-1), which specifically immunolabels hair cells in at least five vertebrate classes, including sharks and rays, bony fish, amphibians, birds, and mammals. We used HCS-1 to immunoprecipitate the cognate antigen and identified it as otoferlin, a member of the ferlin protein family. Mutations in otoferlin underlie DFNB9, a recessive, nonsyndromic form of prelingual deafness characterized as an auditory neuropathy. Using immunocytochemistry, we find that otoferlin is associated with the entire basolateral membrane of the hair cells and with vesicular structures distributed throughout most of the hair cell cytoplasm. Biochemical assays indicate that otoferlin is tightly associated with membranes, as
\end{abstract}

Correspondence to: Guy P. Richardson - School of Life Sciences University of Sussex - Falmer, Brighton, BN1 9QG, UK. Telephone: +44-1273-678717; fax: +44-1273-678433; email: g.p.richardson@sus sex.ac.uk it is not solubilized by alterations in calcium or salt concentrations. HCS-1 immunolabeling does not colocalize with ribeye, a constituent of synaptic ribbons, suggesting that otoferlin may, in addition to its proposed function in synaptic vesicle release, play additional roles in hair cells.

Keywords: balance, hearing, auditory system, vestibular system, ribeye

\section{INTRODUCTION}

Hair cells are the mechanoreceptors of the inner ear that detect sound and accelerations of the head. In fish and aquatic amphibians, hair cells in the lateral line organs detect fluid movements that are important for schooling behaviors, locomotion in turbulence, detection of prey, and the avoidance of predators (Dikgraaf 1933; Ghysen and Dambly-Chaudiere 2007).

Hair cells reside in sensory epithelia with their apically located hair bundles projecting into the lumen of the inner ear where they are poised to detect minute displacements. The hair bundle is a highly organized structure composed of actin-filled stereocilia arranged in rows of increasing height. Deflections of the order of a few nanometers are sufficient to increase the open probability of cation-selective transduction channels 
located at stereociliary tips. Transduction channel opening leads to membrane depolarization and culminates in synaptic vesicle release at synapses located in the basolateral portion of the cell (Hudspeth 1989; LeMasurier and Gillespie 2005). Thus, apical and basolateral regions of the hair cell have distinct functions that are likely to depend upon different sets of proteins. Other subcellular regions within the hair cell include the cuticular plate, an actin-rich meshwork that anchors the hair bundle; the pericuticular necklace, a vesicle-rich region encircling the cuticular plate; and the kinocilium, an axonemal cilium located at the tall edge of the hair bundle.

In all organisms, hair cells are few in number. Approximately 80,000 hair cells are present in the eight hair cell containing end organs of the chicken inner ear, and approximately 12,000 are present in the six end organs in the mouse inner ear. Such low numbers of hair cells, which require harvesting through timeconsuming microdissections of animal ears, make it difficult to biochemically identify and characterize proteins important for hair cell function. The generation of immunological reagents against proteins in the inner ear has proved to be a useful alternative approach to the identification of molecules that are important for auditory and vestibular function (Richardson et al. 1990; Goodyear and Richardson 1992, 1999, 2003; Goodyear et al. 2003; Ahmed et al. 2006; McGee et al. 2006). Accordingly, we have generated a panel of monoclonal antibodies (mAbs) against antigens present in the chicken inner ear. In the current study, we describe one of these antibodies, hair cell soma 1 (HCS-1), which specifically recognizes a protein found in the hair cell soma in a variety of species and has been used by numerous laboratories as a hair cell marker (Gale et al. 2000, 2002; Daudet and Lewis 2005; Forlano et al. 2005; Lopez-Schier and Hudspeth 2005, 2006; Taylor and Forge 2005; Blasiole et al. 2006; Bricaud and Collazo 2006; Hu and Corwin 2007; Warchol and Speck 2007; Ma et al. 2008; Bird et al. 2010). We have used the HCS-1 antibody to immunoprecipitate the antigen it recognizes and have identified this protein by mass spectrometry as otoferlin, a member of the ferlin protein family known to be important for proper auditory function (Yasunaga et al. 1999, 2000; Tekin et al. 2005; Roux et al. 2006; Longo-Guess et al. 2007). Using the HCS-1 antibody, we describe the distribution of otoferlin in chick, fish, guinea pig, and bullfrog inner ears and characterize its biochemical properties.

\section{MATERIALS AND METHODS}

\section{Animals}

All animal procedures followed NIH guidelines and were approved by the Animal Care and Use Commit- tees at the West Virginia University School of Medicine, University of Virginia School of Medicine, Washington University School of Medicine, or the United Kingdom Home Office and the local ethical committee of the University of Sussex.

\section{Antibody generation and purification}

Sensory epithelia were delaminated from the utricles of 1-21 day post-hatch (PH) White Leghorn chicks after treatment with thermolysin (Sigma), $500 \mu \mathrm{g} / \mathrm{ml}$ for $60 \mathrm{~min}$ at $37^{\circ} \mathrm{C}$. The epithelia were lightly fixed in $1 \%$ paraformaldehyde for $15 \mathrm{~min}$, washed by centrifugation, and frozen in liquid nitrogen. Six-week-old female BALB/C mice were injected intraperitoneally with 30 sensory epithelia emulsified in RIBI adjuvant (Ribi Immunochem Research, Hamilton, MT, USA) at day 0 and day 21. At day 60 , an additional 50 sensory epithelia were injected. Four days after the final immunization, each mouse was killed, its spleen was removed, and the splenocytes were fused with SP/0 myeloma cells. Hybridomas were then selected and expanded. Hybridoma supernatants from over 400 wells were screened initially by ELISA on wells coated with $1 \mu \mathrm{g} /$ well of antigen homogenate. Wells that were positive by ELISA were expanded further and secondarily screened by immunohistochemistry on cryostat sections of utricles from chickens. Cells producing supernatants that tested positive by immunohistochemistry were cloned twice by limiting dilution to obtain single clones. The monoclonal antibody used in this study is the HCS-1 antibody, also called mAb76.

\section{Immunoprecipitation}

Dissected tissues that had been harvested and stored at $-80^{\circ} \mathrm{C}$ were solubilized in cold phosphate-buffered saline (PBS; $137 \mathrm{mM} \mathrm{NaCl}, 2.7 \mathrm{mM} \mathrm{KCl}, 4.3 \mathrm{mM}$ $\mathrm{Na}_{2} \mathrm{HPO}_{4}$, and $1.5 \mathrm{mM} \mathrm{KH}_{2} \mathrm{PO}_{4}, \mathrm{pH}$ 7.4) containing a cocktail of protease inhibitors (1 mM PMSF, $2 \mathrm{mM}$ benzamidine, $1 \mu \mathrm{g} / \mathrm{ml}$ leupeptin, and $1 \mu \mathrm{g} / \mathrm{ml}$ pepstatin or $0.2 \mathrm{mM}$ PMSF, $10 \mu \mathrm{g} / \mathrm{ml}$ aprotinin, $0.5 \mu \mathrm{g} / \mathrm{ml}$ leupeptin, and $0.7 \mu \mathrm{g} / \mathrm{ml}$ pepstatin) and $1 \%$ Triton X-100 (TX-100), centrifuged at $15,000_{\operatorname{gmax}}$ for $10 \mathrm{~min}$ at $4^{\circ} \mathrm{C}$, and aliquots of the supernatant were mixed with protein A Sepharose beads (Sigma Aldrich, St. Louis, MO, USA) charged either with mAb HCS-1 or an irrelevant $\mathrm{mAb}$ of the same isotype (anti-HCA mAb H27; Goodyear and Richardson, unpublished) or the anti-V5 antibody (Invitrogen, Carlsbad, CA, USA) overnight. Beads were washed extensively with PBS containing $0.1 \%$ TX-100, and bound proteins were eluted with $2 \times$ concentrated sample buffer $(20 \%$ glycerol, $20 \mathrm{mM}$ EDTA, $250 \mathrm{mM}$ Tris-HCl, $\mathrm{pH} 8.0$, $0.02 \%$ bromophenol blue, $6 \%$ sodium dodecyl sulfate, 
$10 \%$ ß-mercaptoethanol) and analyzed by SDS-PAGE. To determine the solubility of otoferlin, tissues were sequentially extracted in $150 \mathrm{mM} \mathrm{NaCl}, 10 \mathrm{mM}$ sodium phosphate, pH 7.2 (PBS); $5 \mathrm{mM}$ ethylene glycol bis(2aminoethyl ether)- $N, N, N^{\prime} N^{\prime}$-tetraacetic acid in $150 \mathrm{mM}$ $\mathrm{NaCl}, 10 \mathrm{mM}$ HEPES, pH 7.2 (EGTA); $1 \mathrm{M} \mathrm{NaCl}$, $10 \mathrm{mM}$ HEPES, pH 7.2 (High Salt); $10 \mathrm{mM}$ HEPES, pH 7.2 (Low Salt); and $0.1 \%$ TX-100 in $150 \mathrm{mM}$ $\mathrm{NaCl}, 10 \mathrm{mM}$ HEPES, pH 7.2 (TX-100). Extracts were centrifuged at $70,000_{\text {gmax }}$ for $15 \mathrm{~min}$ at $4^{\circ} \mathrm{C}$, and the resultant supernatants were immunoprecipitated in the presence of $0.1 \% \mathrm{TX}-100$ and analyzed as described above.

\section{Mass spectrometry}

Each of the two protein bands precipitated from chick inner ears by mAb HCS-1 was excised from a Coomassie-stained acrylamide gel, and the gel slices were washed in water, reduced, carboxymethylated, and digested with trypsin. The resultant tryptic peptides were desalted, concentrated, and applied to a capillary liquid chromatography system coupled to a quadrupole time-of-flight mass spectrometer (LC-MS/ MS; Qtof2, Waters). The MS/MS data obtained were used to search the NCBI databases employing the MASCOT search engine (http://www.matrixscience. com). Probability-based MASCOT scores were used to evaluate identification; matches with a $P<0.05$ for random occurrence were considered significant.

\section{Immunocytochemistry}

\section{Cryosections of chicken, dogfish, gerbil, and guinea pig}

Chicken, gerbil, and guinea pig tissues were fixed for $1 \mathrm{~h}$ at room temperature in $3.7 \%$ formaldehyde in $0.1 \mathrm{M}$ sodium phosphate buffer, $\mathrm{pH}$ 7.4. Inner ears from the smooth dogfish, Mustelus canis, were fixed in $3.7 \%$ formaldehyde in elasmobranch Ringer's solution $(280 \mathrm{mM} \mathrm{NaCl}, 540 \mathrm{mM}$ urea, $10 \mathrm{mM} \mathrm{KCl}$, $4.5 \mathrm{mM} \mathrm{NaHCO}, 10 \mathrm{mM} \mathrm{CaCl}_{2}, 50 \mu \mathrm{M} \mathrm{NaH}{ }_{2} \mathrm{PO}_{4}$, $0.1 \%$ dextrose; Marine Biological Laboratory Chemical Room, Woods Hole, MA, USA) overnight. Fixed tissues were washed in PBS, cryoprotected with $30 \%$ sucrose in PBS overnight, embedded in $1 \%$ low gelling point agarose (type VII agar, Sigma Aldrich), frozen, and cryosectioned at $-30^{\circ} \mathrm{C}$. Frozen sections were mounted on gelatin-coated slides. Tissues from 3-week-old gerbils and a 3-month-old guinea pig were decalcified in 0.5 M EDTA, $\mathrm{pH} 8.0$, for $24-48 \mathrm{~h}$ prior to cryoprotection; tissues from 2-day-old chicks and mature dogfish were processed without decalcification. Sections were preblocked with $10 \%$ horse serum in Tris-buffered saline (TBS; $10 \mathrm{mM}$ Tris-HCl, $\mathrm{pH}$ 7.4, $150 \mathrm{mM} \mathrm{NaCl}$ ) and incubated overnight at room temperature with either the HCS-1 antibody alone or with mAb HCS-1 and anti-CtBP2 (1:100, BD Biosciences, San Jose, CA, USA), which detects ribeye, anti-Lamp1 (1:500; Abcam Inc, Cambridge, MA, USA), and antiprotein tyrosine phosphatase receptor $\mathrm{Q}$ (anti-Ptprq; 1:100, mAb D10 supernatant) in 10\% horse serum in TBS. Following washing in TBS, bound antibodies were detected with species-specific secondary antibodies (1:200 FITC goat anti-mouse IgG2a, Serotech, Oxford, UK and 1:100 rhodamine swine anti-rabbit, Dako). In samples that were only immunolabeled with the HCS-1 antibody, filamentous actin was stained with Texas Red phalloidin (1:300, Invitrogen). Images were obtained with an Axioskop epifluorescent microscope or a LSM 510 confocal microscope (Zeiss, Thornwood, NY, USA) and colorized with Photoshop7.0 software (Adobe Systems, Inc., San Jose, CA, USA).

\section{Zebrafish cryosections}

Larval zebrafish were euthanized at $72 \mathrm{~h}$ postfertilization and fixed overnight in $4 \%$ paraformaldehyde (prepared in $0.1 \mathrm{M}$ phosphate buffer, $\mathrm{pH}$ 7.4). Following thorough rinsing in PBS, fish were cryoprotected by overnight incubation in 30\% sucrose in PBS, embedded in OCT compound (Miles Diagnostics, Elkhart, IN, USA), and cryosectioned at $10 \mu \mathrm{m}$ thickness. Specimens were blocked in 2\% normal horse serum, 2\% normal goat serum, $1 \%$ bovine serum albumin, and $0.2 \%$ TX-100 in PBS and were then incubated overnight in HCS-1 (1:500) and anti-PAX2 (1:200; Zymed, South San Francisco, CA, USA), with 2\% horse serum and $0.2 \%$ TX-100 in PBS. Sections were then rinsed in PBS and incubated for $2 \mathrm{~h}$ in Alexa-488 anti-mouse IgG (1:500; Invitrogen) and Cy-3 anti-rabbit IgG (1:500; Amersham, Piscataway, NJ, USA). Following washing, specimens were mounted on microscope slides (in 9:1 glycerol/PBS) and imaged on a Nikon Eclipse 2000 inverted microscope with epifluorescent illumination.

\section{Bullfrog saccular wholemounts and isolated cells}

Bullfrog sacculi were fixed in 3\% paraformaldehyde in cold PBS for $25 \mathrm{~min}$, washed in PBS, and permeabilized in $0.1 \%$ TX-100 in PBS for $1 \mathrm{~h}$. Following a PBS wash, the tissue was blocked in 5\% goat serum in PBS for $1 \mathrm{~h}$ and incubated overnight at $4^{\circ} \mathrm{C}$ in $4.5 \mu \mathrm{g} / \mathrm{ml} \mathrm{HCS}-1$ antibody in blocking solution. Bound antibodies were detected with Alexa-488 goat anti-mouse secondary antibody (Invitrogen), and filamentous actin was labeled with $33 \mathrm{nM}$ Alexa-568 phalloidin (Invitrogen). Samples were mounted in Vectashield (Vector Laboratories, Burlingame, CA, USA) and viewed with a LSM 510 META confocal microscope (Zeiss). Isolated bullfrog saccular hair cells (Lumpkin and Hudspeth 1995) were allowed to settle onto coverslip dishes (Mattek, Ashland, MA, 
USA) coated with $1 \mathrm{mg} / \mathrm{ml}$ concanavalin A. The cells were fixed for $25 \mathrm{~min}$ in $3 \%$ paraformaldehyde in cold PBS, washed for $10 \mathrm{~min}$ in PBS, and permeabilized for $20 \mathrm{~min}$ in $0.1 \%$ saponin in PBS. Dishes were washed for $5 \mathrm{~min}$ in PBS and blocked for $1 \mathrm{~h}$ in $10 \mathrm{mg} / \mathrm{ml}$ bovine serum albumin (fraction V; EMD Biosciences, San Diego, CA, USA) and $5 \%$ goat serum in PBS. Primary antibody solutions of $4.5 \mu \mathrm{g} / \mathrm{ml} \mathrm{HCS}$ 1 antibody with or without $2.5 \mu \mathrm{g} / \mathrm{ml} \mathrm{F} 2 \mathrm{~b}$ anti-plasma membrane $\mathrm{Ca}^{2+}$ ATPase b isoform (anti-PMCAb) antibody (Dumont et al. 2001; gift from P. Gillespie, Oregon Health \& Science University) in blocking solution were incubated with the cells overnight at room temperature. Following two 10-min washes with PBS/0.1\% Tween-20, dishes were incubated at room temperature for $2 \mathrm{~h}$ with blocking solution containing $33 \mathrm{nM}$ Alexa-568 phalloidin and either $13 \mu \mathrm{g} / \mathrm{ml}$ Alexa 488 goat anti-mouse antibody alone to detect bound $\mathrm{mAb}$ HCS-1 or $13 \mu \mathrm{g} / \mathrm{ml}$ goat anti-mouse Alexa 488 and $13 \mu \mathrm{g} / \mathrm{ml}$ Alexa-568 goat anti-rabbit (Invitrogen) to visualize both otoferlin and PMCAb. Dishes were then washed $2 \times 10 \mathrm{~min}$ in PBS $/ 0.1 \%$ Tween-20 and $1 \times 10 \mathrm{~min}$ in PBS and mounted in Vectashield. Images were obtained using an LSM 510 META confocal microscope with a $100 \times, 1.4$ NA objective.

\section{Preparation of expression vectors}

Full-length otoferlin was amplified by polymerase chain reaction (PCR) with Pfu polymerase using cDNA from P2 chicken utricle as template. The $5^{\prime}$ half of the cDNA was amplified with primers GgOtofF5 (GATCCGCTAGCCACCATGGCTCTGCAGCTG CAGCT, NheI site underlined) and GgOtofR6 (CAAAGGGATCcGAAAGGCCAC, including a $\mathrm{T}>\mathrm{C}$ point mutation at base 11 to introduce a BamHI site, underlined). PCR product was gel-purified, cut with NheI and BamHI, and ligated into the vector backbone of pEGFP-actin (Clontech) that had been cut with NheI and BamHI, dephosphorylated, and gelpurified to remove the EGFP-actin insert. After transformation into Escherichia coli XL1 blue cells (Stratagene), recombinant plasmids were identified by PCR and by restriction enzyme digestion of plasmid DNA. One plasmid was selected for use in the second cloning step, linearized with BamHI, and dephosphorylated. The $3^{\prime}$ half of the cDNA was amplified as above, using primers GgOtofF7 (GTGGCCTTTCgGATCCCTTTG, including point mutation $A>G$ at base 11 to create a BamHI site, underlined) and GgOtofR4 (CCGGTGGATCCC TATGCCCCCAGGAGCTTCTTGAC, BamHI site underlined). The PCR product was gel-purified, cut with BamHI, and ligated into the prepared plasmid. After transformation into E. coli XL1 Blue, full-length otoferlin clones were identified by PCR and restriction enzyme digests of plasmid DNA. Clone pOtofFL5 was sequenced fully to confirm that the insert encoded fulllength otoferlin. pOtofFL5 was transfected into cells using Lipofectamine 2000. After overnight incubation, cell monolayers were fixed in $3.7 \%$ formaldehyde in $0.1 \mathrm{M}$ sodium phosphate buffer, $\mathrm{pH} 7.5$, blocked in TBS containing $10 \%$ horse serum and $0.1 \%$ TX100 for $1 \mathrm{~h}$, and then incubated overnight with HCS-1 mAb diluted 1 in 500 in TBS plus $10 \%$ horse serum. After washing three times in TBS, Alexa 555 conjugated goat anti-mouse IgG2a ( 1 in 500 in TBS/HS) was added for $1 \mathrm{~h}$, and monolayers were washed three times in TBS, mounted with Vectashield, and photographed on a Zeiss Axioplan fluorescence microscope or a Zeiss LSM510 confocal microscope.

Three overlapping fragments of otoferlin were amplified by PCR with Pfu polymerase (Stratagene) using cDNA from P2 chicken utricle as the template. Products obtained with primer pairs GgOtofF1 (CAGATCTCGAGCTATGGCTCTGCAGCTGCAGCT, XhoI) and GgOtofR1 (CCGGTGGATCCCTAGGG CAGGTAGCCTTTGTCTC, BamHI), GgOtofF2 (CAGATCTCGAGCTCAGT GGGCTCGTTTCTA CATC, XhoI) and GgOtofR2 (CCGGTGGAT CCCTACTGGTAGTATTCCAGCTGTG, BamHI), and

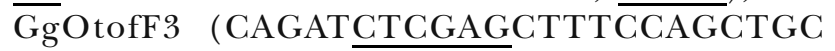

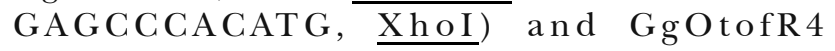
(CCGGTGGATCCCTATGCCCCCAGGAGCTTCTT GAC, BamHI) were gel-purified, digested with XhoI and BamHI, and ligated into XhoI and BamHI cut pEGFP-actin (Clontech). PCR and restriction digests of plasmid DNA were used to identify clones encoding EGFP-otoferlin fusion proteins. All inserts were confirmed to be free of errors by DNA sequencing. All three constructs expressed EGFP-tagged protein in mammalian cells that was not recognized by the HCS$1 \mathrm{mAb}$, possibly as a result of misfolding caused by the tag (data not shown).

\section{RT-PCR}

Total RNA from 1 day post-hatch chick tissues was isolated using Trizol (Invitrogen, Paisley, UK) then treated with RNase-free DNase I to remove traces of genomic DNA (Applied Biosystems, Warrington, UK). Randomly primed first-strand cDNA was synthesized from $1 \mu \mathrm{g}$ of total RNA using AMV reverse transcriptase (Promega, Southampton, UK) and the reaction diluted to $100 \mu \mathrm{l}$ final volume. Otoferlin and GAPDH PCR products were amplified from $2 \mu \mathrm{l}$ aliquots of the reverse transcriptase (RT) reactions using Bioline Taq polymerase (Bioline, UK) and primers GgOtofF3 and GgOtofR2 (see above) and GAPDHF1 (GCTGAGTATGTTGTG GAGTC) and GAPDHR1 (TCAGCAGCAGCCTTCAC TAC). Aliquots $(5 \mu \mathrm{l})$ of the PCR reactions were run on 
$1.5 \%$ agarose gels, stained with ethidium bromide, and photographed under UV illumination.

\section{RESULTS}

Isolation and characterization of hair cell soma-1 antibody

As a means to identify and characterize proteins important for inner ear function, we immunized mice with emulsified chicken inner ear sensory epithelia that had been briefly exposed to a dilute aldehyde fixative. We generated a panel of 400 wells containing hybridoma cells. Supernatants from these wells were initially screened by ELISA on a chicken inner ear homogenate. Cells from the wells that gave a positive signal by ELISA were subsequently expanded and screened by immunohistochemistry on frozen sections of chicken utricles. Using this approach, 40 antibodies were isolated that recognized proteins in specific cell types of the inner ear. Of these, four antibodies were further characterized: two $\operatorname{IgG}_{2 b}$ antibodies bound specifically to supporting cells (data not shown), one IgM antibody bound to the cuticular plate of the hair cell (data not shown), and one $\operatorname{IgG}_{2 \mathrm{a}}$ antibody bound to an antigen specifically found in the hair cell soma. This latter antibody was named the HCS-1 antibody.

The specific localization of the HCS-1 antigen to the soma of utricular hair cells (Fig. 1A) led us to further examine its expression in other hair cell containing end organs in a variety of species. In the chicken, the HCS-1 antigen was present in all hair cells of the basilar papilla (Fig. 1B and data not shown) and other hair cell containing end organs (data not shown). In the inner ear of the guinea pig (Fig. 1C, D) and gerbil (not shown), the HCS-1 antigen was present in the inner hair cells of the cochlea, but not in the outer hair cells, and was detectable at low levels in the vestibular hair cells of the maculae. In addition, the HCS-1 antigen was present in the utricular, saccular, and lateral line hair cells in zebrafish (Fig. 1E); in the utricular and saccular hair cells of the dogfish (Fig. 1F and data not shown); and in the saccular hair cells of the bullfrog (Fig. 1G). This mAb does not detect denatured protein on immunoblots (data not shown) suggesting that it recognizes a conformation-dependent epitope.

\section{Hair cell soma-1 antigen is otoferlin}

To identify the HCS-1 antigen, we used the antibody to immunoprecipitate proteins from a Triton X-100 soluble extract of the chicken inner ear and subjected the immunoprecipitated protein to mass spectrometry. When resolved by SDS-PAGE, the immunoprecipitated
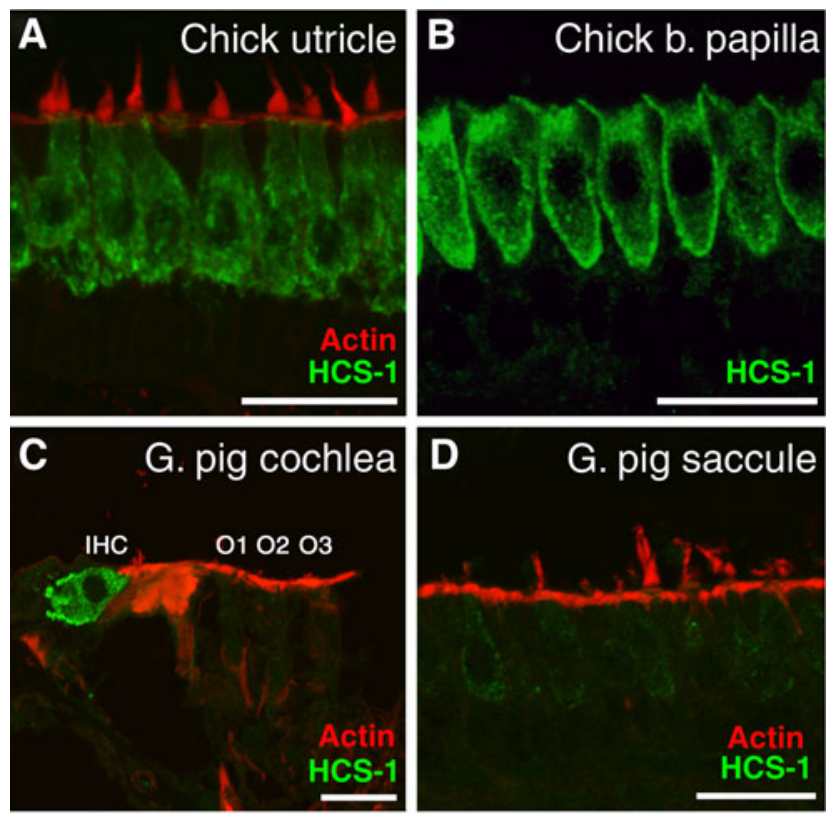

$\mathbf{E}$

Zebrafish
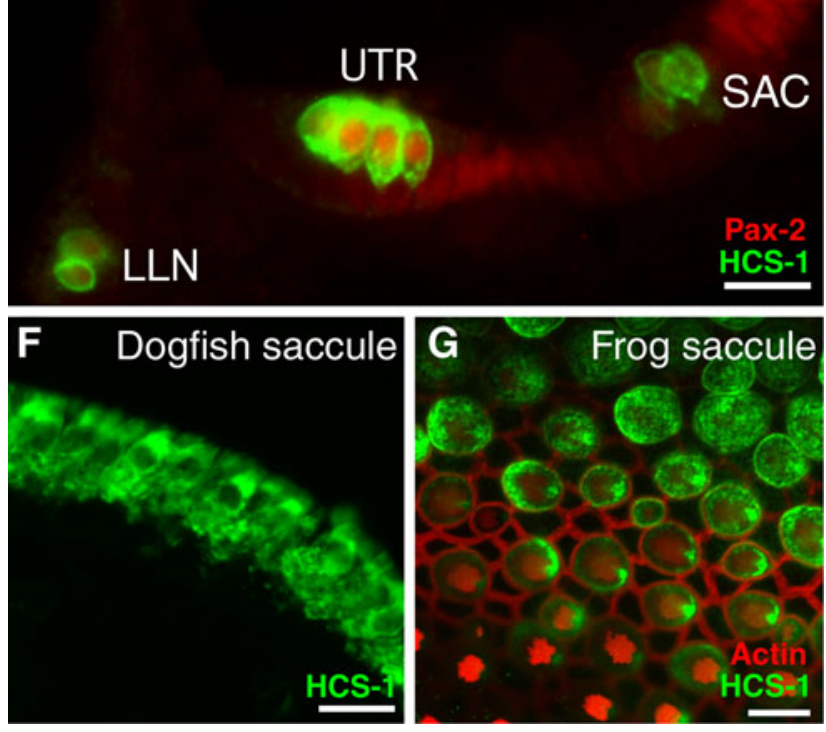

FIG. 1. HCS-1 antigen is present in hair cells of a variety of species. A, B The HCS-1 antibody (green) labels the soma of hair cells in the utricle and basilar papilla of the early post-hatch (2-day-old) chicken inner ear. C, D In the young adult guinea pig ( $\sim 3$ months of age), the HCS-1 antibody (green) labels cochlear inner hair cells (IHC), but not outer hair cells (O1-O3), and also weakly labels saccular hair cells. E The HCS-1 antibody (green) labels hair cells in the utricle (UTR), sacculus (SAC), and in the lateral line (LLN) of the larval zebrafish at 5 days post-fertilization. PAX2 expression (red) was detected within nuclei of cells of the sensory epithelium as well as within the developing CNS. F In the sacculus of the mature adult dogfish, the HCS-1 antibody specifically labels hair cell somas. G In the adult bullfrog sacculus, the HCS-1 antibody labels hair cell somas. Note that this confocal image of a whole-mount preparation optically sections the epithelium at a shallow angle revealing the hair bundles at the apical surface and the hair cell somas underneath. In panels B, C, D, and G, fluorescently conjugated phalloidin (red) labels filamentous actin. Scale bars in panels $\mathbf{A}-\mathbf{D}$ and $\mathbf{F}=25 \mu \mathrm{m}$, scale bars in $\mathbf{E}$ and $\mathbf{G}=10 \mu \mathrm{m}$. 
A

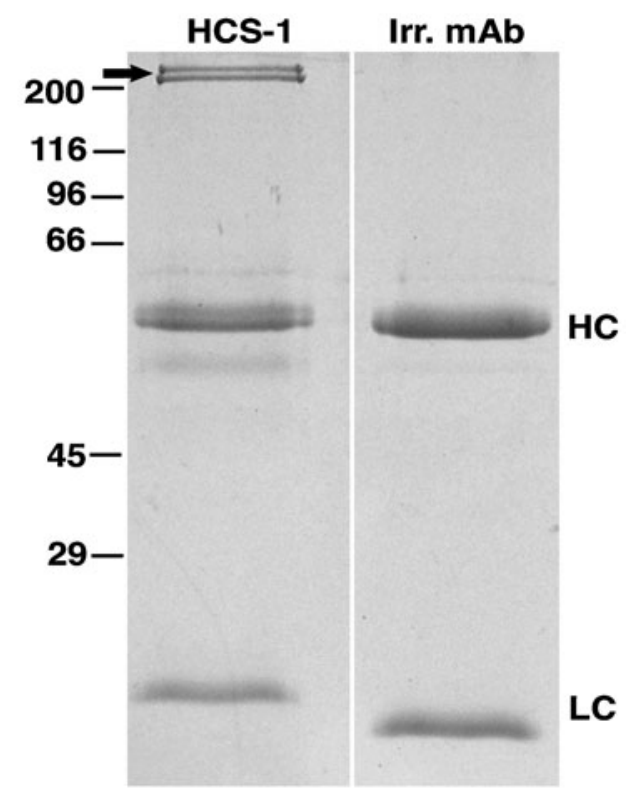

B MALIVHLKTV SELRGKGDRI AKVTFRGQSF YSRVLENCEG VADFDETFRW PVASSIDRNE VLEIQIFNYS KVFSNKLIGT FCMVLQKVVE ENRVEVTDTL MDDSNAIIKT SLSMEVRYQA TDGTVGPWDD GDFLGDESLO EEKDSOETDG LLPGSRPSTR ISGEKSFRSK GREETKGGRD GEHKAGRSVF SAMKLGKTRS HKEEPQRQDE PAVLEMEDLD HLAIQLGDGL DPDSVSLASV TALTSNVSNK RSKPDIKMEP.SAGRPMDYQY. SITYIEARQL VGLNMDPVVC VEVGDDKKYT SMKESTNCPY YNEYFVFDFH VSPDVMFDKI IKISVIHSKN LLRSGTLVGS FKMDVGTVYS QPEHQFHHKW AILSDPDDIS AGLKGYVKCD VAVVGKGDNI KTPHKANETD EDDIEGNLLL PEGVPPERQW ARFYVKIYRA EGLPRMNTSL. MANYKKAFIG ENKDLVDPYV QVFFAGQKGK TSVQKSSYEP LWNEQVVFTD LFPPLCKRMK VOIRDSDKVN DVATGTHFID LRKISNDGDK GFLPTLGPAW VNMYGSTRNY TLLDEHQDLN EGLGEGVSFR ARLMLGLAVE ILDTSNPELT SSTEVQVEQA TPVSESCTGR MEEFFLFGAF LEASMIDRKN GDKPITFEVT IGNYGNEVDG MSRPLRPRPR KEPGDEEEVD LIQNSSDDEG DEAGDLASVS STPPMRPQIT DRNYFHLPYL ERKPCIYIKS WWPDQRRRLY NANIMDHIAD KLEEGLNDVQ EMIKTEKSYP ERRLRGVLEE LSCGCHRFLS LSDKDQGRSS RTRLDRERLK SCMRELESMG QQAKSLRAQV KRHTVRDKLR LCQNFLQKLR FLADEPQHSI PDVFIWMMSN NKRIAYARVP SKDLLFSIVE EELGKDCAKV KTLFLKLPGK RGFGSAGWTV QAKLELYLWL GLSKQRKDFL CGLPCGFEEV KAAQGLGLHS FPPISLVYTK KQAFQLRAHM YQARSLFAAD SSGLSDPFAR VFFINQSQCT EVLNETLCPT WDQMLVFDNL ELYGEAHELR DDPPIIVIEI YDQDSMGKAD FMGRTFAKPL VKMADEAYCP PRFPPQLEYY OIYRGSATAG DLLAAFELLQ IGPSGKADLP PINGPVDMDR GPIMPVPVGI RPVLSKYRVE VLFWGLRDLK RVNLAQVDRP RVDIECAGKG VQSSLIHNYK KNPNFNTLVK WFEYPLPENE LLHPPLNIRV VDCRAFGRYT LVGSHAVSSL RRFIYRPPDR SAPNWNTTGE VVVSMEPEEP VKKLETMVKL DATSDAVVKV DVAEDEKERK KKKKKGPSEE PEEEEPDESM LDWWSKYFAS IDTMKEQLRQ HETSGTDLEE KEEMESAEGL KGPMKSKEKS RAAKEEKKKK NQSPGPGQGS EAPEKKKAKI DELKVYPKEL ESEFDSFEDW LHTFNLLRGK TGDDEDGSTE EERIVGRFKG SLCVYKVPLP EDVSREAGYD PTYGMFOGIP SNDPINVLVR IYVVRATDLH PADINGKADP YIAIKLGKTD IRDKENYISK QLNPVFGKSF DIEASFPMES MLTVAVYDWD LVGTDDLIGE TKIDLENRFY SKHRATCGIA QTYSIHGYNI WRDPMKPSQI LTRLCKEGKV DGPHFGPHGR VRVANRVFTG PSEIEDENGQ RKPTDEHVAL SALRHWEDIP RVGCRLVPEH VETRPLLNPD KPGIEQGRLE LWVDMFPMDM PAPGTPLDIS PRKPKKYELR VIVWNTDEVV LEDDDFFTGE KSSDIFVRGW LKGQQEDKQD TDVHYHSLTG EGNFNWRYLF PFDYLAAEEK IVMSKKESMF SWDETEYKIP ARLTLQIWDA DHFSÄDDFLG AIELDL̈NRFP RGAKTAKQCT MEMATGEVDV PLVSIFKOKR VKGWWPLLAR NENDEFELTG KVEAELHLLT AEEAEKNPVG LARNEPDPLE KPNRPDTAFV WFLNPLKSIK YLICTRYKWL IIKIVLALLG LLMLALFLYS LPGYMVKKLL GA
60

120

180

240

300

360

420

480

540

600

660

720

780

840

900

960

1020

1080

1140

1200

1260

1320

1380

1440

1500

1560

1620

1680

1740

1800

1860

1920

1980

1992
FIG. 2. Identification of HCS-1 antigen as otoferlin. A Immunoprecipitation from chick sensory epithelia using the HCS-1 antibody. Coomassie-stained SDS-PAGE gel revealing a high molecular weight doublet immunoprecipitated from a Triton X-100 extract of chicken inner ear (arrow, left lane). These proteins were not immunoprecipitated with the $\mathrm{H} 27$ antibody, an isotype-matched irrelevant antibody (right lane). Immunoprecipitated bands were excised and subjected to mass spectrometry. Bands corresponding to the immunoglobulin heavy- and light chains are indicated by $H C$ and $L C$, respectively. Molecular mass markers in kilodaltons are indicated to the left. B
Location of tryptic peptides in the sequence of mouse cochlear otoferlin. Tryptic digestion followed by mass spectrometry identified seven peptides unique to the otoferlin sequence for the $230-\mathrm{kDa}$ immunoprecipitated protein (underlined). One of these peptides (italics and double underlined) overlapped a larger peptide. The 210$\mathrm{kDa}$ immunoprecipitated protein identified six of the same peptides obtained for the higher molecular weight band and an additional six peptides (underlined with asterisks).

cultures with the HCS-1 antibody. HCS-1 immunoreactive cells were observed in cultures that had been transfected with otoferlin alone (Fig. 3A) but not in cells that had been sham-transfected (Fig. 3B) or transfected with espin-EGFP alone (not shown). In polarized epithelial cell lines that had been cotransfected with both plasmids, otoferlin was detected within the cell soma (Fig. 3C) but not within the highly elongated microvilli that form on the apical surface of the cell in response to espin over-expression (Fig. 3D). Otoferlin is therefore excluded from the microvilli of polarized epithelial cells lines in vitro, as it is from the stereocilia of hair cells in vivo. We also transiently over-expressed three C-terminally EGFP-tagged otoferlin fragments that together encompassed the entire open reading frame of otoferlin in a number of different cell lines, including HEK 293, MDCK, and Caco2 cells, and in supporting cells in primary cultures derived from the chicken utricle. Immunoreactivity for HCS-1 was not detected in any cell type expressing any of these otoferlin constructs (not shown) suggesting that the combination of both plasmids and then stained the 
fragments do not fold correctly and providing further evidence that HCS-1 recognizes an epitope that depends on the tertiary structure of the protein.

\section{Otoferlin expression and localization}

Recent reports have demonstrated a role for otoferlin protein in auditory hair cell synaptic vesicle release (Roux et al. 2006; Heidrych et al. 2009). Using the HCS-1 antibody, we first sought to determine the tissue distribution of the otoferlin protein in the chick. Otoferlin immunoreactivity was not detected in cryosections of the chicken forebrain, cerebellum, gizzard, heart, intestine, kidney, liver, lung, muscle, retina, skin, or tongue (Fig. $4 \mathrm{~A}-\mathrm{L}$ ) but was in utricle (Fig. 4M). Using RT-PCR with primers that span two introns and should only amplify a 381-bp fragment from cDNA, expression was detected in at least four of these tissues (forebrain, cerebellum, kidney, and retina; Fig. 4N). HCS-1 may either recognize an earspecific epitope or an epitope that is masked in all tissues other than the ear. Alternatively, it may only detect cells in which otoferlin is expressed at very high levels.
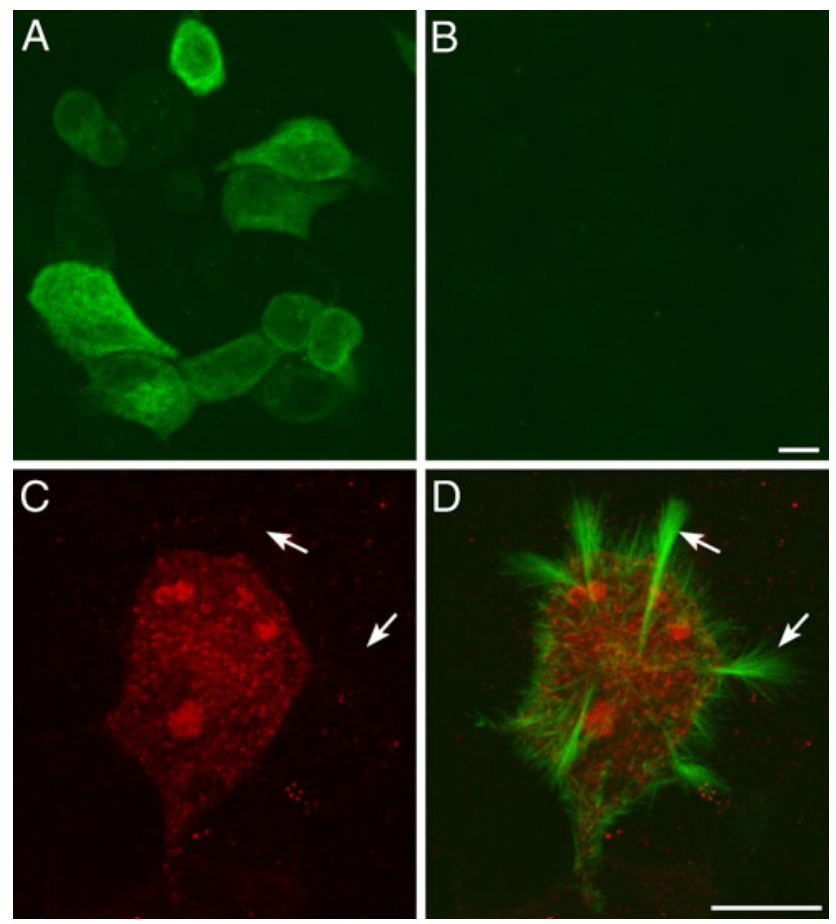

FIG. 3. HCS-1 antibody staining of transfected cell lines. A HEK293 cells transfected with plasmid construct encoding the full-length form of chick otoferlin stained with the HCS-1 antibody. B Shamtransfected HEK-293 cells stained with the HCS-1 antibody. C, D Caco-2 cell co-transfected with plasmid construct encoding a fulllength form of chick otoferlin and a plasmid encoding EGFP-espin doubled-labeled with HCS-1 antibody (red in C, D) and antibody to EGFP (green in D). Arrows indicate the highly elongated microvilli that form on the EGFP-espin transfected cells. Scale bars $=10 \mu \mathrm{m}$.
During inner ear development, otoferlin immunoreactivity was detected as early as E7 in the distal end of the chick basilar papilla, in a region where Ptprq (Goodyear et al. 1997) expression is detected by the HCA antibody (Fig. 5). Otoferlin staining clearly revealed that immature hair cells possess a thin cytoplasmic process that extends down to the basal surface of the epithelium (Fig. 5, E7-E8). As the hair cells mature, these processes retract (Fig. 5, E10). Double labeling studies with HCS-1 mAb and antibodies to the hair cell marker myosin VI at E7 and E8 (Fig. 6) indicate that HCS-1 immunoreactivity is confined to cells and cellular processes in which myosin VI can be detected. HCS-1 is therefore unlikely to be expressed by either supporting cells or hair cell progenitors.

In mature chick hair cells, double labeling for otoferlin and Lamp1, a marker for lysosomes and late endosomes (Griffiths et al. 1988), did not reveal a significant degree of co-localization (Fig. 7A). Colabeling for otoferlin and ribeye, a known synaptic ribbon protein (Schmitz et al. 2000), failed to reveal any apparent co-localization of these two proteins in chick hair cells (Fig. 7B). Also, there was no evidence for otoferlin expression at the ribeye-positive synaptic ribbons that were immunolabeled within retinal photoreceptors and bipolar cells (Fig. 7C). In cryosections of chick basilar papilla, double immunolabeling for otoferlin and PMCAb (Fig. 7D), an isoform of the plasma membrane calcium ATPase (Dumont et al. 2001), indicates that otoferlin is associated with the basolateral membrane of the hair cell.

To better appreciate the expression of otoferlin at the subcellular level, we examined the bullfrog sacculus, the hair cells of which are relatively large and can readily be isolated from the sensory epithelium. We first confirmed antibody specificity in this tissue by immunoprecipitation. As seen for the chick inner ear, the HCS-1 antibody immunoprecipitated a doublet in the $225-\mathrm{kDa}$ region from bullfrog saccules (Fig. 8A). Additional co-immunoprecipitating proteins were not evident on silver-stained SDS-PAGE gels, although some proteins may have been masked by the presence of the immunoglobulin heavy and light chains (Fig. 8A). In whole-mount preparations of the sacculus, otoferlin immunoreactivity is restricted to hair cells where it is abundant in the soma and, as in the chick, appears to be localized to the basolateral membrane (Fig. 1G and see Gale et al. 2000). As in the whole-mount preparations, otoferlin was present along the basolateral membrane of the isolated hair cells and in membranous structures within the cytoplasm of the isolated cells. This immunoreactivity substantially overlapped with that of the PMCAb (Fig. 8B), an abundant hair cell integral membrane protein (Dumont et al. 2001). In the cytoplasm of bullfrog hair cells, otoferlin was most often seen 
enriched in a region immediately between the cuticular plate and the nucleus (Fig. 8B). The patterns of otoferlin immunoreactivity in the isolated bullfrog hair cells and in the intact saccular epithelium did not show discrete "hot spots" in the basolateral portion of the cell as might be expected if the protein was specifically localized to the $\sim 20$ synaptic dense bodies present in that location (Issa and Hudspeth 1996; Lenzi et al. 1999). In a subset of isolated bullfrog saccular hair cells, an enrichment of otoferlin in the perinuclear region of the cell was observed. The localization in this region appeared to be related to the apparent health of the cells and was present in cells that contained large perinuclear vacuoles, which also were PMCAb immunopositive, and may be an indicator of the damage caused by the isolation procedure (data not shown). In approximately $30 \%$ of the isolated bullfrog saccular hair cells, otoferlin immunoreactivity was also present in the apical membrane (data not shown). We did not, however, observe apical membrane labeling in the whole-mount preparations of the bullfrog sacculus.

\section{Solubility of hair cell otoferlin}

To assess whether otoferlin is, as predicted, a transmembrane protein, we sequentially subjected chicken inner ear tissue with buffered saline containing a calcium chelator, high salt, low salt, and $0.1 \%$ Triton $\mathrm{X}-100$ and then subjected the soluble protein fraction following each treatment to immunoprecipitation. Of these treatments, only extraction with $0.1 \%$ Triton $\mathrm{X}-100$ resulted in the release of otoferlin into the soluble protein fraction (Fig. 9) suggesting that both isoforms are transmembrane proteins.

\section{DISCUSSION}

The identification and characterization of hair cellspecific proteins has been hindered by the relatively small numbers of hair cells that can be harvested from the inner ears of most vertebrates. We have used the monoclonal antibody, HCS-1, to immunoprecipitate its cognate antigen from chicken inner ears. Using mass spectroscopy, we have identified the antigen as otoferlin. We describe the expression of otoferlin across a number of species, its tissue distribution, subcellular localization, and developmental profile.

On the basis of its primary sequence, otoferlin is predicted to be a large single-pass transmembrane protein containing three to six protein kinase $\mathrm{C}$ conserved region 2 (C2) domains (Yasunaga et al. 1999). C2 domains are membrane-targeting regions that mediate $\mathrm{Ca}^{2+}$-dependent membrane interactions (Cho and Stahelin 2006; Lemmon 2008). Highly expressed in the inner ear, otoferlin mRNA is also present in other tissues including the brain, liver, lung and heart, kidney, and testis (Yasunaga et al. 1999, 2000; Schug et al. 2006). Transcripts encoding two classes of otoferlin isoforms, resulting from alternative splicing, have been detected by RT-PCR in the human brain and cochlea. The predicted long isoforms $(\sim 230 \mathrm{kDa})$ contain all six C2 domains while the short isoforms $(\sim 140 \mathrm{kDa})$ contain only the last three C2 domains (Schmitz et al. 2000; Yasunaga et al. 2000). RT-PCR data suggest that only the larger otoferlin isoforms are present in the mouse brain and cochlea (Yasunaga et al. 2000). The HCS-1 antibody immunoprecipitates bands from chicken and frog inner ears that are consistent with the presence of transcripts encoding the larger otoferlin isoforms. Shorter isoforms could also be present in these ears, but may not be precipitated by this monoclonal antibody. Interestingly, HCS-1 immunoprecipitation of the chicken and frog inner ear lysates reveals two large otoferlin protein isoforms that migrate at $\sim 210$ and $230 \mathrm{kDa}$. Cochlear splice variants have not been described that would account for these two bands (Yasunaga et al. 2000), suggesting they may differ in apparent mass as a consequence of posttranslational modification. These immunoprecipitated proteins are not, however, recognized by antibodies against phosphorylated serine, threonine, or tyrosine residues (data not shown), suggesting that the observed heterogeneity is not due to phosphorylation. Both protein isoforms appear to be tightly associated with cell membranes and are not extracted by calcium chelation or either high- or low-ionic strength buffers suggesting that both isoforms contain the hydrophobic C-terminal domain and are indeed transmembrane proteins.

The HCS-1 antibody detects otoferlin located in hair cells of chick, zebrafish, dogfish, and frog inner ears, as well as hair cells in the zebrafish lateral line. These findings indicate that the epitope recognized by the HCS-1 antibody is conserved across many species and at least four vertebrate classes. In chick, the antibody is highly specific for hair cells and the antigen is not detected in organs other than the ear, indicating there may be hair cell-specific isoforms of otoferlin, that the expression levels of otoferlin in other cell types is much lower than in hair cells, or that the epitope is masked in those tissues in which expression can be detected by RT-PCR (i.e., brain, retina, and kidney). Consistent with previous reports of otoferlin mRNA and protein expression in adult mouse and rat cochlea (Judice et al. 2002; Roux et al. 2006; Schug et al. 2006; Brandt et al. 2007), otoferlin immunoreactivity is only detected in the inner hair cells of the adult guinea pig and gerbil cochlea. In the adult guinea pig saccule, HCS-1 immunoreactivity is weak. We do, however, detect robust otoferlin immu- 


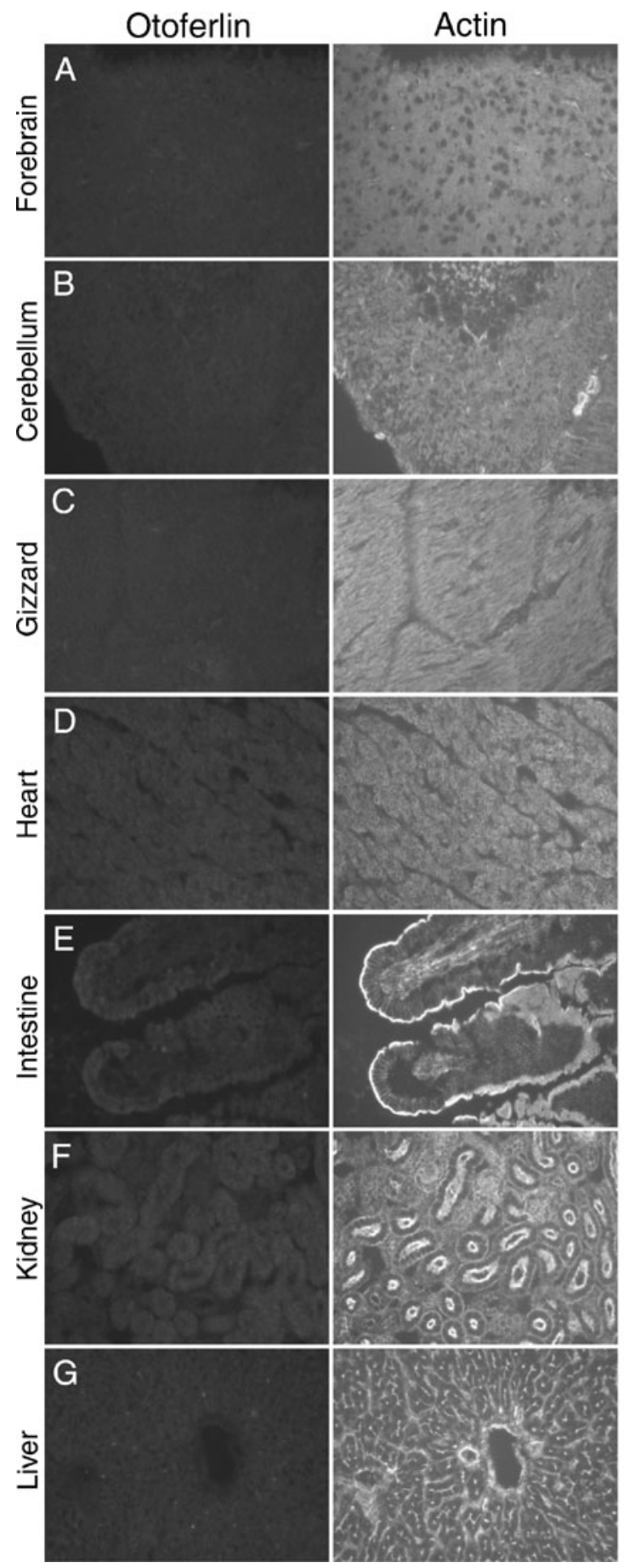

FIG. 4. HCS-1 antibody staining and otoferlin RT-PCR of multiple chick tissues. A-N Double labeling with the HCS-1 antibody (otoferlin) and phalloidin (F-actin) of cryosections of forebrain (A), cerebellum $(\mathbf{B})$, gizzard $(\mathbf{C})$, heart $(\mathbf{D})$, intestine $(\mathbf{E})$, kidney $(\mathbf{F})$, liver $(\mathbf{G})$, lung $(\mathbf{H})$, muscle $(\mathbf{I})$, retina $(\mathbf{J})$, skin $(\mathbf{K})$, tongue $(\mathbf{L})$, and utricle $(\mathbf{M})$ from the 1-day PH chicken. Scale bar in $\mathbf{M}$ is $40 \mu \mathrm{m}$ and applies to all panels. N RT-PCR products for otoferlin (Otof) and glyceraldehyde 3-phosphate dehydrogenase $(G A P D H)$ were amplified by RT-PCR

noreactivity in vestibular hair cells of chick, zebrafish, frog, and dogfish, and others have shown that otoferlin protein is present in the vestibular hair cells of the rat and mouse (Yasunaga et al. 1999; Roux et al.

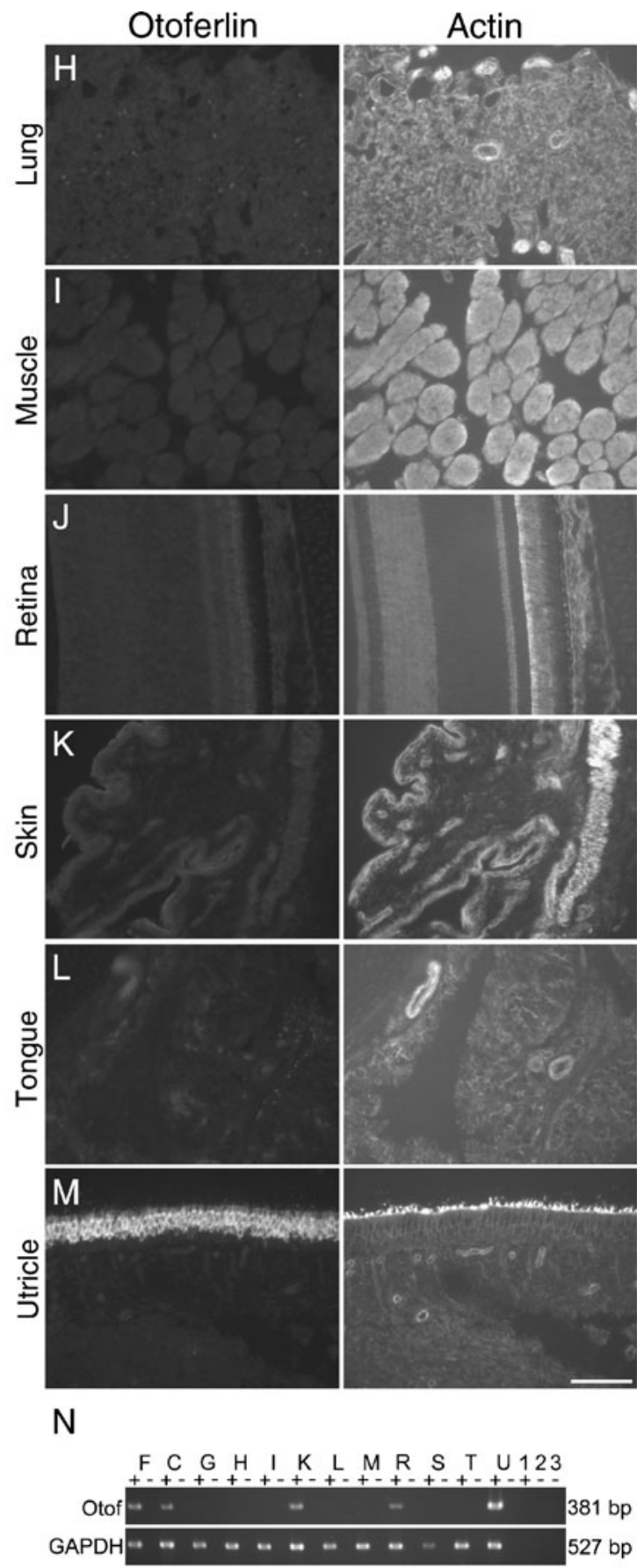

from total RNA prepared from 1 day $\mathrm{PH}$ chick forebrain $(F)$, cerebellum $(C)$, gizzard $(G)$, heart $(H)$, intestine $(I)$, kidney $(K)$, lung $(L)$, skeletal muscle $(M)$, retina $(R)$, skin $(S)$, tongue $(T)$, and utricle $(U)$. 1, 2 Reverse transcription controls with no RNA added; 3 PCR reaction control. Reverse transcription reactions were performed with $(+)$ or without $(-)$ AMV reverse transcriptase. Otoferlin mRNA expression was detected in forebrain, cerebellum, kidney, retina, and utricle.

2006; Schug et al. 2006). We attribute the reduced immunoreactivity in the guinea pig sacculus to the properties of the HCS-1 antibody, which appears to have limited ability to recognize otoferlin in some 
Ptprq
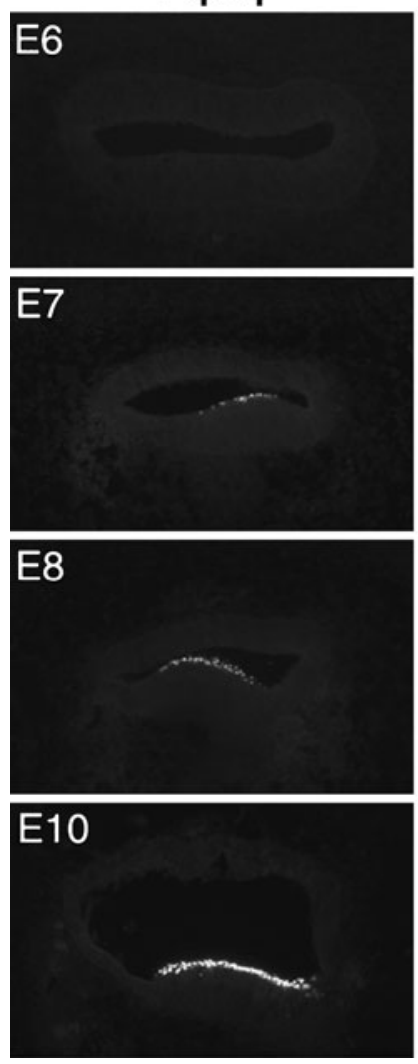

FIG. 5. Developmental expression of otoferlin in the chick basilar papilla. Immunolocalization of otoferlin (HCS-1 antibody right) in cryosections of the chick basilar papilla at embryonic $(E)$ day 6 to E10. Immunolabeling for Ptprq with the HCA antibody (left) was performed on adjacent sections to identify the hair cells. The first otoferlin immunopositive hair cells are detected at E7 (arrowhead) and have long basally directed, HCS-1-stained, cytoplasmic tails (arrow). Scale bar $=50 \mu \mathrm{m}$ and applies to all panels.

mammalian species including mouse (data not shown).

The HCS-1 antibody detects hair cells in the basilar papilla of the developing chick as early as E7. Hair cells have been detected in this organ with the HCA $\mathrm{mAb}$ and with a Tuj1 antibody at E6.5 (Bartolami et al. 1991; Molea et al. 1999). Otoferlin is therefore expressed within $12 \mathrm{~h}$ of some of the earliest markers for hair cell differentiation, and its expression patterns at these early stages clearly reveal that differentiating hair cells retain a cytoplasmic tail that extends right down to the basal surface of the epithelium (Fig. 6), as has been described previously for regenerating hair cells in the chick and the frog (Girod et al. 1989; Steyger et al. 1997; Stone and Rubel 2000).

In mature hair cells, otoferlin is predominately cytoplasmic and in bullfrog saccular hair cells it is enriched in the supranuclear cytoplasm, the region between the nucleus and the cuticular plate. It also is present in the basolateral plasma membrane where it co-localizes with the membrane protein PMCA2b. After isolation of bullfrog saccular hair cells, otoferlin immunoreactivity was also detected at the apical membrane in a subset of the hair cells. We did not, however, observe apical membrane labeling in the hair cells present within the whole-mounted tissue suggesting that disruption of the cellular junctions, which delineate the apical and basolateral membrane domains, can alter the subcellular localization of this protein and that this protein may undergo specific targeting and relatively dynamic regulation.

Otoferlin is the member of the ferlin family of proteins and shares the highest protein sequence identity with dysferlin, a protein proposed to play an important role in plasma membrane repair (Bansal and Campbell 2004). Such repair occurs through the fusion of dysferlin-containing lysosomal vesicles to the plasma membrane. The similarity between dysferlin and otoferlin suggests that otoferlin may play a role in membrane-fusion events. While otoferlin is present near the basolateral membrane of hair cells, the lack of significant co-localization with Lamp1, a lysosomal and late endosomal marker (Griffiths et al. 1988), implies that it may not be involved in general membrane repair.
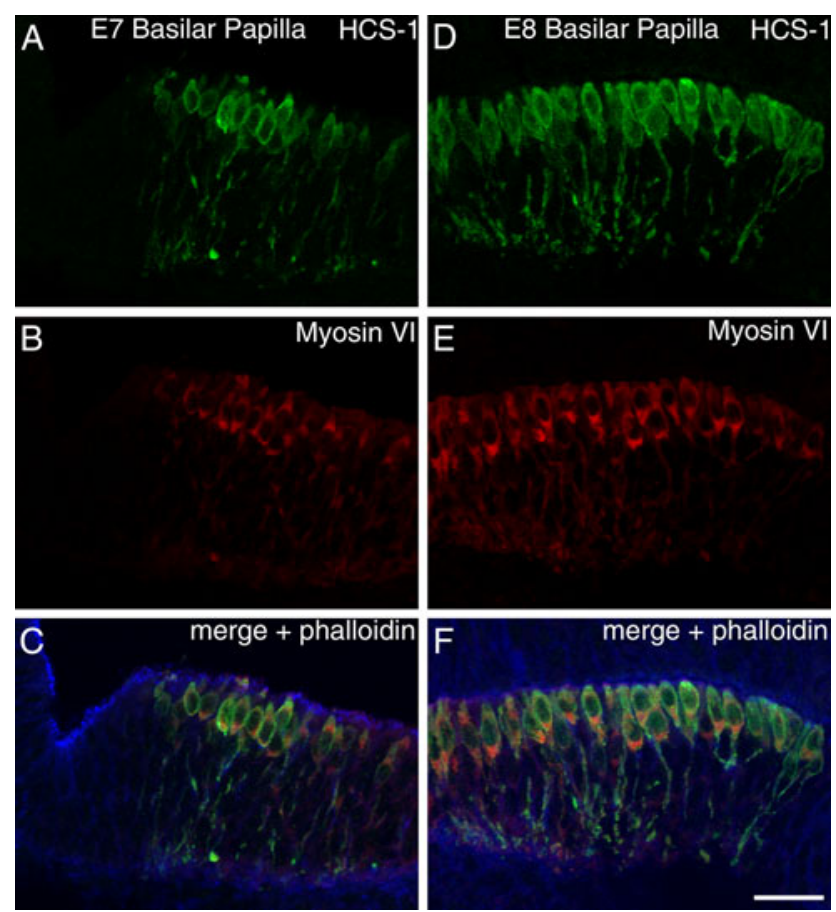

FIG. 6. Distribution of myosin $\mathrm{VI}$ and otoferlin in the embryonic basilar papilla. Triple labeling for otoferlin (HCS-1 mAb in green, $\mathbf{A}$ and $\mathbf{D}$ ), myosin VI (anti-myosin VI in red, $\mathbf{B}$ and $\mathbf{E}$ ), and F-actin (blue in $\mathbf{C}$ and $\mathbf{F}$ ) in cryosections of the embryonic chicken basilar papilla at E7 (A-C) and E8 (D-F). Individual channels are shown for otoferlin in panels $\mathbf{A}$ and $\mathbf{D}$ and for myosin VI in panels $\mathbf{B}$ and $\mathbf{E}$. Merges for all three channels are shown in panels $\mathbf{C}$ and $\mathbf{F}$. Bar $=20 \mu \mathrm{m}$. 

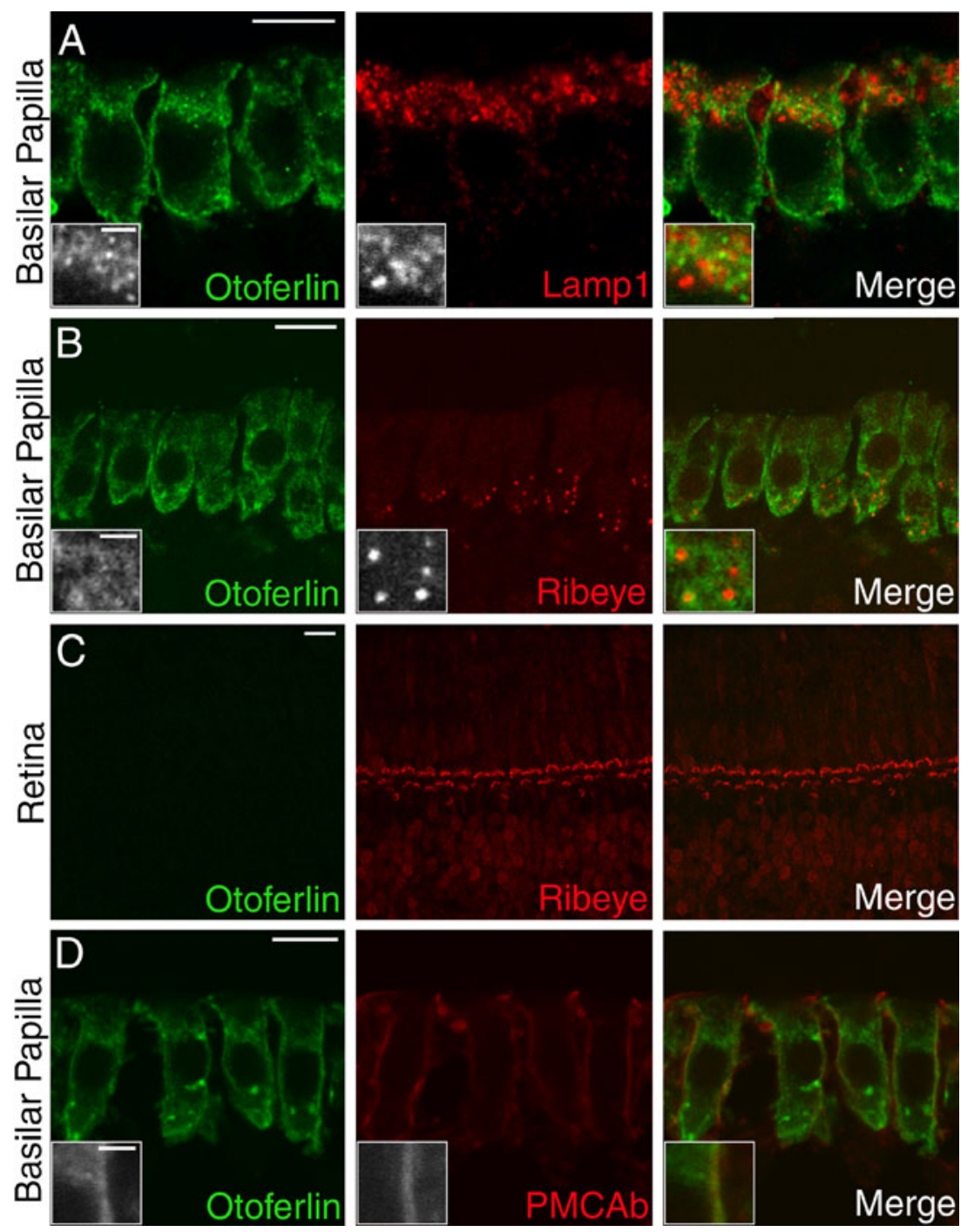

FIG. 7. Immunolocalization of otoferlin, Lamp1, ribeye, and PMCAb in chicken tissues. Confocal microscopy images of cryosections from chicken basilar papilla $(\mathbf{A}, \mathbf{B}$, and $\mathbf{D})$ and retina $(\mathbf{C})$ doublelabeled in green with antibodies to otoferlin (HCS-1 antibody) and, in red, antibodies to either A Lamp1; a marker for lysosomes and late endosomes; B, C ribeye, the synaptic ribbon marker labeled with the anti-CtBP2 antibody, or D PMCAb, a component of the hair cell's basolateral membrane. Scale bars in $\mathbf{A}-\mathbf{D}=10 \mu \mathrm{m}$; scale bars in insets= $2 \mu \mathrm{m}$.

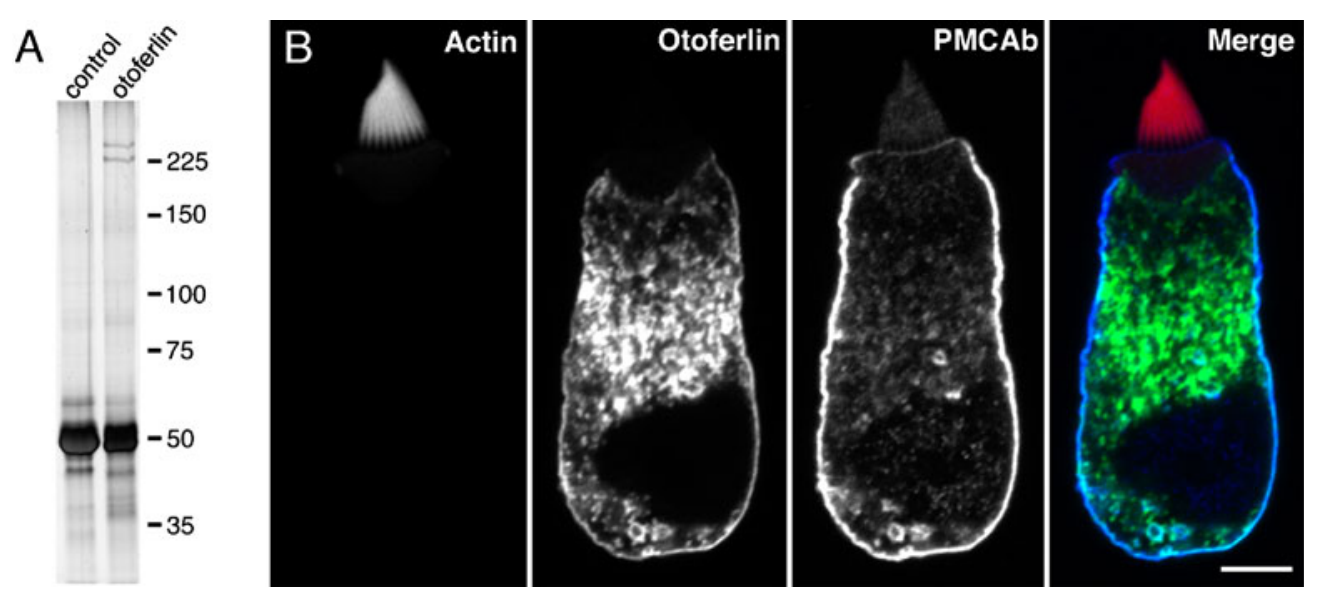

FIG. 8. Immunoprecipitation of otoferlin from bullfrog saccule and subcellular localization in isolated bullfrog saccular hair cells. A Silver stain of a SDS-PAGE gel containing proteins immunoprecipitated from bullfrog sacculus with the anti-otoferlin antibody (HCS-1) or an irrelevant isotype-matched control antibody (anti-V5 antibody). Immunoglobulin heavy chain is observed at approximately $50 \mathrm{kDa}$.
Molecular mass markers in kilodaltons are indicated to the right. B Confocal localization of actin (red), otoferlin (HCS-1 antibody, green), and PMCAb (blue) in an isolated saccular hair cell by confocal microscopy. Individual channels are shown to the left, merged image is shown to the right. Scale bar $=5 \mu \mathrm{m}$. 


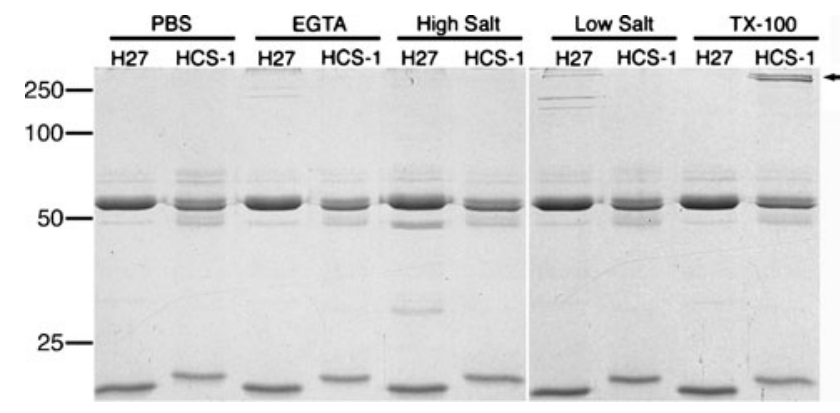

FIG. 9. Solubility of otoferlin in the chick inner ear. Coomassieblue stained SDS-PAGE gel of proteins immunoprecipitated from PBS, 5 mM EGTA, $1 \mathrm{M} \mathrm{NaCl}$ (high salt), $10 \mathrm{mM}$ HEPES (low salt), or $0.1 \%$ Triton X-100 extracts of chicken inner ear. Each extract was immunoprecipitated with either the anti-otoferlin antibody (HCS-1) or an irrelevant isotype-matched antibody (mAb H27). Otoferlin is only immunoprecipitated from the TX-100 extract (arrow). The bands of approximately 55 and $20 \mathrm{kDa}$ correspond to the IgG heavy chain and light chain, respectively. Molecular mass markers in kilodaltons are indicated to the left.

Mutations in the human otoferlin gene result in nonsyndromic prelingual deafness, DFNB9, a recessive auditory neuropathy (Yasunaga et al. 1999; Rodriguez-Ballesteros et al. 2003; Varga et al. 2003, 2006; Tekin et al. 2005; Choi et al. 2009) and mice that carry otoferlin mutations also exhibit auditory deficits (Roux et al. 2006; Longo-Guess et al. 2007). Inner hair cells from otoferlin knockout animals exhibit impaired calcium-evoked exocytosis (Roux et al. 2006), as do immature outer hair cells (Beurg et al. 2008) leading to the hypothesis that otoferlin is critical for synaptic vesicle release in cochlear hair cells and that it may serve a role similar to the function of synaptotagmin in nerve terminals (Roux et al. 2006). Otoferlin has been shown to associate with syntaxin 1A, SNAP-25 (Roux et al. 2006; Ramakrishnan et al. 2009) and L-type $\mathrm{Ca}^{2+}$ channels (Ramakrishnan et al. 2009); however, it also interacts with myosin VI (Heidrych et al. 2009). Moreover, inner hair cells from hypothyroid rats exhibit exocytotic profiles similar to those in immature inner hair cells despite lacking otoferlin mRNA and protein (Brandt et al. 2007), and although otoferlin is expressed at high levels in vestibular hair cells (Yasunaga et al. 1999; Roux et al. 2006; Schug et al. 2006), vestibular function is unaffected in otoferlin mutants (Longo-Guess et al. 2007; Schwander et al. 2007). Otoferlin is not, therefore, essential for synaptic vesicle release in all types of hair cell. Otoferlin does not co-localize with ribeye, a synaptic ribbon protein, in the chick basilar papilla nor is it enriched in discrete regions that might correlate to the $\sim 20$ presynaptic dense bodies found in bullfrog saccular hair cells (Issa and Hudspeth 1996; Lenzi et al. 1999). In addition, otoferlin is highly expressed in both the superior and inferior regions of the chick basilar papilla, both during development and in the mature organ (data not shown), despite hair cells in the inferior region having little, if any, afferent innervation. Collectively, these data suggest that otoferlin may play additional roles in hair cells that are yet to be defined.

\section{ACKNOWLEDGMENTS}

Dr. Janet L. Cyr was originally involved in this work when she was at West Virginia University School of Medicine. The authors would like to thank Dr. Kelli Phillips for experimental advice and dissections; Dr. Kathryn Lilley, Cambridge Centre for Proteomics, UK for her assistance; James Finley for technical support; Shirley House for instruction in monoclonal antibody production; Dr. Peter Gillespie for the anti-PMCAb antibody; and Dr. Jim Bartles for the EGFP-espin construct. This work was supported by NIH/NIDCD grants R01DC006402 (previously to JLC), RO1DC00200 (JTC), and R01DC006283 and P30DC04665 (MEW) and NIH/NCRR grant P20RR015574 (WVU Sensory Neuroscience Research Center), The Wellcome Trust (JEG, RJG, GPR), a Royal Society University Research Fellowship (JEG), and a PhD Studentship from The Royal National Institute for Deaf People (JK). A portion of this work was performed at the Marine Biological Laboratory, Woods Hole, MA.

\section{Open Access}

This article is distributed under the terms of the Creative Commons Attribution Noncommercial License which permits any noncommercial use, distribution, and reproduction in any medium, provided the original author(s) and source are credited.

\section{REFERENCES}

Ahmed ZM, Goodyear R, Riazuddin S, Lagziel A, Legan PK, Behra M, Burgess SM, Lilley KS, Wilcox ER, Riazuddin S, Griffith AJ, Frolenkov GI, Belyantseva IA, Richardson GP, Friedman TB (2006) The tip-link antigen, a protein associated with the transduction complex of sensory hair cells, is protocadherin-15. J Neurosci 26:7022-7034

Bansal D, Campbell KP (2004) Dysferlin and the plasma membrane repair in muscular dystrophy. Trends Cell Biol 14:206-213

Bartolami S, Goodyear R, Richardson G (1991) Appearance and distribution of the $275 \mathrm{kD}$ hair-cell antigen during development of the avian inner ear. J Comp Neurol 314:777-788

Beurg M, Safieddine S, Roux I, Bouleau Y, Petit C, Dulon D (2008) Calcium- and otoferlin-dependent exocytosis by immature outer hair cells. J Neurosci 28:1798-1803

Bird JE, Daudet N, Warchol ME, Gale JE (2010) Supporting cells eliminate dying sensory hair cells to maintain epithelial integrity in the avian inner ear. J Neurosci (in press)

Blasiole B, Canfield VA, Vollrath MA, Huss D, Mohideen MA, Dickman JD, Cheng KC, Fekete DM, Levenson R (2006) Separate Na,KATPase genes are required for otolith formation and semicircular canal development in zebrafish. Dev Biol 294:148-160

Brandt N, Kuhn S, Munkner S, Braig C, Winter H, Blin N, Vonthein R, Knipper M, Engel J (2007) Thyroid hormone deficiency affects 
postnatal spiking activity and expression of $\mathrm{Ca}^{2+}$ and $\mathrm{K}^{+}$channels in rodent inner hair cells. J Neurosci 27:3174-3186

Bricaud O, Collazo A (2006) The transcription factor six1 inhibits neuronal and promotes hair cell fate in the developing zebrafish (Danio rerio) inner ear. J Neurosci 26:10438-10451

Chо W, Stahelin RV (2006) Membrane binding and subcellular targeting of C2 domains. Biochim Biophys Acta 1761:838-849

Chor BY, Ahmed ZM, Riazuddin S, Bhinder MA, Shahzad M, Husnain T, Riazuddin S, Griffith AJ, Friedman TB (2009) Identities and frequencies of the otoferlin gene (OTOF) causing DFNB9 deafness in Pakistan. Clin Gent 75:237-243

DAUdET N, LewIS J (2005) Two contrasting roles for Notch activity in chick inner ear development: specification of prosensory patches and lateral inhibition of hair-cell differentiation. Development 132:541-551

DikgRAAF S (1933) Untersuchungen uber die Funktion der seitenorgane an fischen. J Comp Physiol A 20:162-214

Dumont RA, Lins U, Filoteo AG, Penniston JT, Kachar B, Gillespie PG (2001) Plasma membrane $\mathrm{Ca}^{2+}$-ATPase isoform 2a is the PMCA of hair bundles. J Neurosci 21:5066-5078

Ebermann I, Walger M, Scholl HP, Charbel Issa P, Luke C, Nurnberg G, Lang-Roth R, Becker C, Nurnberg P, Bolz HJ (2007) Truncating mutation of the DFNB59 gene causes cochlear hearing impairment and central vestibular dysfunction. Hum Mutat 28:571-2007

Forlano PM, Deitcher DL, Bass AH (2005) Distribution of estrogen receptor alpha mRNA in the brain and inner ear of a vocal fish with comparisons to sites of aromatase expression. J Comp Neurol 483:91-113

Gale JE, Meyers JR, Corwin JT (2000) Solitary hair cells are distributed throughout the extramacular epithelium in the bullfrog's saccule. J Assoc Res Otolaryngol 1:172-182

Gale Je, Meyers JR, Periasamy A, Corwin JT (2002) Survival of bundleless hair cells and subsequent bundle replacement in the bullfrog's saccule. J Neurobiol 50:81-92

Ghysen A, Dambli-Chaudiere C (2007) The lateral line microcosmos. Genes Dev 21:2118-2130

Girod DA, Ducker LG, Rubel EW (1989) Possible precursors of regenerated hair cells in the avian cochlea following acoustic trauma. Hear Res 42:175-194

Goodyear R, Richardson G (1992) Distribution of the $275 \mathrm{kD}$ hair cell antigen and cell surface specializations on auditory and vestibular hair bundles in the chicken inner ear. J Comp Neurol 325:243-256

Goodyear R, Richardson G (1997) Pattern formation in the basilar papilla: evidence for cell rearrangement. J Neurosci 17:6239-6231

GoOdyeAr R, Richardson G (1999) The ankle-link antigen: an epitope sensitive to calcium chelation associated with the haircell surface and the calycal processes of photoreceptors. J Neurosci 19:3761-3772

GoOdYEAR RJ, Richardson GP (2003) A novel antigen sensitive to calcium chelation that is associated with the tip links and kinocilial links of sensory hair bundles. J Neurosci 23:4878-4887

Goodyear RJ, Legan PK, Wright MB, Marcotti W, Oganesian A, Coats SA, Booth CJ, Kros CJ, Seifert RA, Bowen-Pope DF, RICHARDSON GP (2003) A receptor-like inositol lipid phosphatase is required for the maturation of developing cochlear hair bundles. J Neurosci 23:9208-9219

Griffiths G, Hoflack B, Simons K, Mellman I, Kornfeld S (1988) The mannose 6-phosphate receptor and the biogenesis of lysosomes. Cell 52:329-341

Heidrych P, Zimmerman U, Kuhn S, Franz C, Engel J, Dunckner SV, Hirt B, Pusch CM, Ruth P, Pfister M, Marcotti W, Blin N, KNIPPER M (2009) Otoferlin interacts with myosin VI: implications for maintenance of the basolateral synaptic structure of the inner hair cell. Hum Mol Genet 18:2779-2790

Hu Z, CoRwIN JT (2007) Inner ear hair cells produced in vitro by a mesenchymal-to-epithelial transition. Proc Natl Acad Sci USA 104:16675-16680
HudsPeth AJ (1989) How the ear's works work. Nature 341:397-404

IsSA NP, HuDSPETH AJ (1996) Characterization of fluo-3 labeling of dense bodies at the hair cell's presynaptic active zone. J Neurocytol 25:257-266

Judice TN, Nelson NC, Beisel Cl, Delimont DC, Fritzsch B, Beisel KW (2002) Cochlear whole mount in situ hybridization: identification of longitudinal and radial gradients. Brain Res Brain Res Protoc 9:65-76

LeMasurier M, Gillespie PG (2005) Hair-cell mechanotransduction and cochlear amplification. Neuron 48:403-415

Lemmon MA (2008) Membrane recognition by phospholipid-binding domains. Nat Rev Mol Cell Biol 9:99-111

Lenzi D, Runyeon JW, Crum J, Ellisman MH, Roberts WM (1999) Synaptic vesicle populations in saccular hair cells reconstructed by electron tomography. J Neurosci 19:119-132

Longo-Guess C, Gagnon LH, Bergstrom DE, Johnson KR (2007) A missense mutation in the conserved C2B domain of otoferlin causes deafness in a new mouse model of DFNB9. Hear Res 234:21-28

Lopez-Schier H, Hudspeth AJ (2005) Supernumerary neuromasts in the posterior lateral line of zebrafish lacking peripheral glia. Proc Natl Acad Sci USA 102:1496-1501

LOPEZ-SCHIER H, HUdSPETH AJ (2006) A two-step mechanism underlies the planar polarization of regenerating sensory hair cells. Proc Natl Acad Sci USA 103:18615-18620

Lumpkin EA, Hudspeth AJ (1995) Detection of $\mathrm{Ca}^{2+}$ entry through mechanosensitive channels localizes the site of mechanoelectrical transduction in hair cells. Proc Natl Acad Sci USA 92:10297-10301

Ma EY, Rubel EW, Raible DW (2008) Notch signaling regulates the extent of hair cell regeneration in the zebrafish lateral line. J Neurosci 28:2261-2273

McGee J, Goodyear RJ, McMillan DR, Stauffer EA, Holt JR, Locke KG, Birch DG, Legan PK, White PC, Walsh EJ, Richardson GP (2006) The very large G-protein-coupled receptor VLGR1: a component of the ankle link complex required for the normal development of auditory hair bundles. J Neurosci 26:6543-6553

Migliosi V, Modamio-Hoybjor S, Moreno-Pelayo MA, Rodriguez-Ballesteros M, Villamar M, Telleria D, Menendez I, Moreno F, Del Castillo I (2002) Q829X, a novel mutation in the gene encoding otoferlin (OTOF), is frequently found in Spanish patients with prelingual non-syndromic hearing loss. J Med Genet 39:502-506

Mirghomizadeh F, Pfister M, Apaydin F, Petit C, Kupka S, Pusch CM, ZenNer HP, Blin N (2002) Substitutions in the conserved C2C domain of otoferlin cause DFNB9, a form of nonsyndromic autosomal recessive deafness. Neurobiol Dis 10:157-164

Molea D, Stone JS, Rubel EW (1999) Class III beta-tubulin expression in sensory and nonsensory regions of the developing avian inner ear. J Comp Neurol 406:183-198

Ramakrishnan NA, Drescher MJ, Drescher DG (2009) Direct interaction of otoferlin with syntaxin $1 \mathrm{~A}, \mathrm{SNAP}-25$ and the Ltype voltage-gated calcium channel. J Biol Chem 16:13641372

Richardson GP, Bartolami S, Russell IJ (1990) Identification of a $275-\mathrm{kD}$ protein associated with the apical surfaces of sensory hair cells in the avian inner ear. J Cell Biol 110:1055-1066

Rodriguez-Ballesteros M, del Castillo FJ, Martin Y, Moreno-Pelayo ma, Morera C, Prieto F, Marco J, Morant A, Gallo-Teran J, Morales-Angulo C, Navas C, Trinidad G, Tapia MC, Moreno F, DEL CASTILlo I (2003) Auditory neuropathy in patients carrying mutations in the otoferlin gene (OTOF). Hum Mutat 22:451456

Roux I, Safieddine S, Nouvian R, Grati M, Simmler MC, Bahloul A, Perfettini I, Le Gall M, Rostaing P, Hamard G, Triller A, Avan P, Moser T, Petit C (2006) Otoferlin, defective in a human deafness form, is essential for exocytosis at the auditory ribbon synapse. Cell 127:277-289 
Schmitz F, Konigstorfer A, SudHof TC (2000) RIBEYE, a component of synaptic ribbons: a protein's journey through evolution provides insight into synaptic ribbon function. Neuron 28:857-872

Schug N, Braig C, Zimmermann U, Engel J, Winter H, Ruth P, Buin N, Pfister M, Kalbacher H, Knipper M (2006) Differential expression of otoferlin in brain, vestibular system, immature and mature cochlea of the rat. Eur J Neurosci 24:3372-3380

SchWANder M, ScZaniecka A, Grillet N, Bailey JS, Avenarius M, Najmabadi H, Steffy BM, Federe GC, Lagler EA, Banan R, Hice R, GrabowskiBoase L, Keithley EM, Ryan AF, Housley GD, Wiltshire T, Smith RJ, TARNTINo LM, Muller U (2007) A forward genetics screen in mice identifies recessive deafness traits and reveals that pejvakin is essential for outer hair cell function. J Neurosci 27:2163-2173

Steyger PS, Burton M, Hawkins JR, Schuff NR, Baird RA (1997) Calbindin and parvalbumin are early markers of non-mitotically regenerating hair cells in the bullfrog vestibular otolith organs. Int J Dev Neurosci 15:417-432

Stone JS, Rubel EW (2000) Temporal, spatial, and morphologic features of hair cell regeneration in the avian basilar papilla. J Comp Neurol 417:1-16

TAYLOR RR, Forge A (2005) Hair cell regeneration in sensory epithelia from the inner ear of a urodele amphibian. J Comp Neurol 484:105-120
Tekin M, Akcayoz D, Incesulu A (2005) A novel missense mutation in a C2 domain of OTOF results in autosomal recessive auditory neuropathy. Am J Med Genet A 138:6-10

Varga R, Kelley PM, Keats BJ, Starr A, Leal SM, Cohn E, Kimberling WJ (2003) Non-syndromic recessive auditory neuropathy is the result of mutations in the otoferlin (OTOF) gene. J Med Genet $40: 45-50$

Varga R, Avenarius mr, Kelley PM, Keats BJ, Berlin Ci, Hood LJ, Morlet TG, Brashears SM, Starr A, Cohn ES, Smith RJ, Kimberling WJ (2006) OTOF mutations revealed by genetic analysis of hearing loss families including a potential temperature sensitive auditory neuropathy allele. J Med Genet 43:576-581

WARCHOL ME, SPECK JD (2007) Expression of GATA3 and tenascin in the avian vestibular maculae: normative patterns and changes during sensory regeneration. J Comp Neurol 500:646-657

Yasunaga S, Grati M, Cohen-Salmon M, El-Amraoui A, Mustapha M, Salem N, El-Zir E, Loiselet J, Petit C (1999) A mutation in OTOF, encoding otoferlin, a FER-1-like protein, causes DFNB9, a nonsyndromic form of deafness. Nat Genet 21:363-369

Yasunaga S, Grati M, Chardenoux S, Smith TN, Friedman TB, Lalwani AK, Wilcox ER, PetrT C (2000) OTOF encodes multiple long and short isoforms: genetic evidence that the long ones underlie recessive deafness DFNB9. Am J Hum Genet 67:591-600 